\title{
KEMAMPUAN GURU SD DALAM MENGEMBANGKAN KETERAMPILAN BERPIKIR KREATIF PADA PELAJARAN IPA
}

\author{
Yuli Nurul Fauziah \\ Wahyu Sopandi \\ Mubiar Agustin \\ Prodi Pendidikan Dasar, Sekolah Pascasarjana Universitas Pendidikan Indonesia
}

\begin{abstract}
This study aims to analyze the ability of elementary school teacher to develop creative thinking skills in teaching science. The research was conducted at grade 5 of 11 elementary schools in the city of Bandung during the 2010-2011 school year. Research subjects were 5 certified teachers through portfolio program, 5 certified teachers through training program, and 5 uncertified teachers. Data collection include analyzing lesson plans, observing learning processes, recording the process of learning through vidoegraph and conducting evaluation tests. Data were analyzed based on the characteristics of creative thinking; which were fluency, flexibility, originality and elaborateness. Results revealed that elementary school teacher had drawn up plans to develop creative thinking skills in their lesson plans, but still could not implemented them in learning activities in classroom. It was concluded that the development of creative thinking skills in science teaching had not been executed effectively. It is suggested that teachers should be encouraged to carry out the learning process that is able to develop creative thinking skills.
\end{abstract}

Keywords: creative thinking, elementary school science

Pelajaran Ilmu Pengetahuan Alam (IPA) pada hakekatnya adalah produk, proses, sikap dan teknologi. Oleh karena itu, sebagai bagian dari proses pendidikan nasional, pembelajaran IPA sebaiknya dilaksanakan secara inkuiri ilmiah (scientific inquiry) agar dapat menumbuhkan kemampuan berpikir, bekerja dan bersikap ilmiah serta mengkomunikasikannya sebagai aspek penting kecakapan hidup (BSNP, 2006). Pembelajaran inkuiri merupakan pembelajaran yang menekankan pada penemuan sesuatu melalui proses mencari dengan menggunakan langkahlangkah ilmiah. Dalam inkuiri, siswa diharapkan kritis menemukan masalah dalam kehidupan dan mencari penyelesaian secara kreatif.

Agar dapat mempelajari IPA secara inkuiri ilmiah, pembelajaran IPA harus didukung dengan keterampilan berpikir. Pembelajaran IPA harus bersifat hands on dan minds on (Firman \&Widodo, 2008). Menurut Filsaime, (2008), berpikir kreatif adalah proses berpikir yang memiliki ciri-ciri kelancaran (fluency), keluwesan (flexibility), keaslian atau originalitas (originality) dan merinci atau elaborasi (elaborate). Kelancaran adalah kemampuan mengeluarkan ide atau gagasan yang benar sebanyak mungkin secara jelas. Keluwesan adalah kemampuan untuk mengeluarkan banyak ide atau gagasan yang beragam dan tidak monoton dengan melihat dari berbagai sudut pandang. Originalitas adalah kemampuan untuk mengeluarkan ide atau gagasan yang unik dan tidak biasa, misalnya yang berbeda dari yang ada di buku atau berbeda dari pendapat orang lain. Elaborasi adalah kemampuan untuk menjelaskan faktor-faktor yang mempengaruhi dan menambah kerincian dari ide atau gagasannya sehingga lebih bernilai. 
Proses pembelajaran melibatkan beberapa komponen diantaranya adalah perencanaan dan pelaksanaan kegiatan pembelajaran. Sudah menjadi tugas guru untuk membuat persiapan mengajar atau membuat Rencana Pelaksanaan Pembelajaran (RPP) dan melaksanakan RPP dalam kegiatan belajar. Perencanaan pembelajaran akan menentukan kualitas pembelajaran yang dilaksanakan. Jika perencanaan baik maka pembelajaran akan baik pula (Rustaman, 2005). Berpikir kreatif dapat dikembangkan pada pembelajaran IPA melalui beberapa metode atau pendekatan, misalnya melalui pembelajaran inkuiri (Pulaila, et.al, 2007; Budiman, et.al, 2008; Cheng, 2010). Metode yang dapat mengembangkan keterampilan berpikir kreatif adalah demonstrasi, diskusi atau tanya jawab (Suastra, 2008).

Saat ini, pendidikan berpikir di tingkat pendidikan dasar belum tertangani secara sistematis dan dilaksanakan secara parsial. Akibatnya, kemampuan berpikir lulusan SD masih sangat rendah (Rofi'uddin, 2009), karena dasar-dasar berpikir tidak dikuasai dengan baik, sehingga dampaknya dirasakan sampai pendidikan menengah dan pendidikan tinggi. Beberapa hasil penelitian menunjukkan rendahnya kemampuan berpikir yang dimiliki oleh siswa sekolah menengah, mahasiswa S1, bahkan juga mahasiswa S2 (Rofi'uddin, 2009).

Oleh karena itu, diperlukan transformasi pendidikan IPA yaitu dari belajar dengan menghafal menjadi belajar berpikir atau dari belajar yang dangkal menjadi mendalam atau kompleks (Suastra, 2008). Peserta didik harus diperkenalkan dengan IPA sebagai mata pelajaran yang menarik karena bisa membantu untuk memahami tentang dunia dan diri sendiri (Jarvis, 1991). Pembelajaran IPA harus bisa meningkatkan daya imaginasi, kreativitasdan logika dalam berpikir.

Penelitian ini difokuskan kepada upaya yang dilakukan guru IPA di sekolah dasar dalam mengembangkan keterampilan berpikir kreatif. Dalam proses pembelajaran, guru merupakan ujung tombak yang berhubungan langsung dengan siswa sebagai subjek dan objek belajar (Sanjaya, 2009). Peningkatan mutu pendidikan tidak terlepas dari peningkatan mutu guru (Raka, 2009). Dalam Undang-undang No.14 Tahun 2005 tentang Guru dan Dosen ditegaskan bahwa guru yang berkualitas secara nasional harus memiliki 4 (empat) kunci kompetensi yaitu pedagogik, profesional, kepribadian, dan sosial (Jalal,et.al.,2009) yang diakui dalam sertifikat pendidik.

Penelitian dilakukan di kelas V karena siswa kelas V SD yang berusia antara 11 dan 12 tahun memiliki perkembangan berpikir pada tahap operasional konkrit. Pada tahap operasional konkrit, pembelajaran tidak semestinya hanya terpaku pada mempelajari konsep melainkan siswa harus terlibat dalam kegiatan yang langsung berinteraksi dengan objek yang dipelajari (Rustaman, 2005). Selain itu, menurut Piaget (dalam Siegler dan Alibali, 2005), karakteristik berpikir anak pada periode operasional konkrit (berusia antara 6 atau 7 sampai 11 atau 12) dapat mengambil butir lain dari suatu masalah, dan dapat secara simultan menemukan perspektif lain. Luasnya perspektif ini berpontensi untuk menyelesaikan macam-macam masalah. Kemampuan berpikir siswa SD kelas V di atas dapat menjadi modal untuk mengembangkan keterampilan berpikir kreatif yaitu keterampilan berpikir yang memiliki ciri dapat mengajukan macam-macam solusi suatu permasalahan serta lancar,mengajukan banyak ide yang sifatnya original secara individu.

Penelitian ini menggunakan metode deskriptif kuantitatif. Subjek penelitian yang dilibatkan adalah 15 orang guru kelas V sekolah dasar yang mengajar mata pelajaran IImu Pengetahuan Alam (IPA) yang dikelompokkan menjadi kelompok guru tersertifikasi melalui portofolio (5 orang), tersertifikasi diklat (5 orang) dan tidak tersertifikasi (5 orang). Pengumpulan data dilakukan melalui analisis Rencana Pelaksanaan Pembelajaran (RPP) dan observasi pembelajaran (direkam dengan video). Jumlah RPP guru yang dianalisis sebanyak 41 buah dan jumlah video pembelajaran yang dianalisis sebanyak 41 buah. Proses koding dan transkrip dalam analisis video pelaksanaan 
pembelajaran dilakukan dengan menggunakan software "Videograph" yang khusus dirancang untuk menganalisis video (Rimmele dalam Widodo, 2006). Tahap pelaksanaan penelitian mencakup langkah-langkah berikut.

a. Menganalisis RPP yang dikembangkan guru

b. Merekam proses pembelajaran IPA yang dilakukan oleh guru SD kelas V. Proses pembelajaran IPA yang direkam untuk masing-masing guru dilakukan sebanyak tiga kali, kecuali ada 4 (empat) guru yang direkam sebanyak dua kali.

c. Menganalisis hasil rekaman proses pembelajaran IPA.

d. Melaksanakan tes kemampuan berpikir kreatif siswa yang berkaitan dengan materi pelajaran IPA yang telah berlangsung.

Instrumen penelitian terdiri dari lembar analisis RPP, lembar observasi pembelajaran, angket guru, angket siswa dan tes keterampilan berpikir kreatif siswa. Lembar analisis RPP menilai seberapa RPP yang dibuat guru mengembangkan aspek-aspek keterampilan berpikir kreatif yang meliputi kelancaran, keluwesan, originalitas dan elaborasi,. Adapun kisi-kisi instrument ada pada Lampiran 1.

\section{HASIL DAN PEMBAHASAN}

\section{Pengembangan Keterampilan Berpikir Kreatif Dalam Perencanaan Pembelajaran}

Proses analisis RPP guru dilakukan dengan cara melihat ada tidaknya setiap aspek

keterampilan berpikir kreatif pada rumusan kegiatan pembelajaran dari setiap RPP. Misalnya dalam kegiatan inti guru merumuskan kegiatan pembelajaran "Siswa dan guru melakukan tanya jawab tentang kegunaan pesawat sederhana dalam kehidupan". Melalui rumusan kegiatan tersebut maka dapat diketahui bahwa guru mengembangkan kelancaran karena melalui tanya jawab siswa mengemukakan jawaban-jawaban yang merupakan pencerminan dari keterampilan berpikirnya. Cara yang sama juga dilakukan untuk mengetahui pengembangan aspek keterampilan berpikir kreatif lainnya. Untuk setiap aspek berpikir kreatif yang muncul maka lembar observasi diberi kode "1" dan jika tidak diberi kode "0". Data hasil analisis RPP guru disajikan pada Tabel 1.

Tabel 1. Dinamika Tiap Aspek Keterampilan Berpikir Kreatif Dalam Rencana Pembelajaran

\begin{tabular}{ccccccc}
\hline \multirow{2}{*}{ Guru } & Pembelajaran & \multicolumn{4}{c}{ Aspek keterampilan berpikir kreatif } & \multirow{2}{*}{$\begin{array}{c}\text { Persentase setiap } \\
\text { guru }\end{array}$} \\
\cline { 3 - 6 } & & Kelancaran & Keluwesan & Originalitas & Elaborasi & \\
\hline 1 & 1 & 1 & 1 & 0 & 0 & 37.5 \\
2 & 1 & 1 & 0 & 0 & 0 & 33.3 \\
& 2 & 1 & 0 & 0 & 1 & \\
& 2 & 1 & 0 & 0 & 0 & \\
3 & 3 & 1 & 0 & 0 & 0 & \\
& 1 & 1 & 0 & 0 & 1 & 50 \\
& 2 & 1 & 0 & 0 & 1 & \\
\hline
\end{tabular}


Tabel 1. (lanjutan)

\begin{tabular}{|c|c|c|c|c|c|c|}
\hline \multirow[t]{2}{*}{ Guru } & \multirow[t]{2}{*}{ Pembelajaran } & \multicolumn{4}{|c|}{ Aspek keterampilan berpikir kreatif } & \multirow{2}{*}{$\begin{array}{c}\text { Persentase setiap } \\
\text { guru }\end{array}$} \\
\hline & & Kelancaran & Keluwesan & Originalitas & Elaborasi & \\
\hline & 3 & 1 & 0 & 0 & 0 & \\
\hline \multirow[t]{2}{*}{5} & 1 & 1 & 1 & 0 & 1 & 75 \\
\hline & 2 & 1 & 1 & 0 & 1 & \\
\hline \multirow[t]{3}{*}{6} & 1 & 1 & 0 & 0 & 0 & 33.3 \\
\hline & 2 & 1 & 1 & 0 & 0 & \\
\hline & 3 & 1 & 0 & 0 & 0 & \\
\hline \multirow[t]{3}{*}{7} & 1 & 1 & 0 & 0 & 0 & 25 \\
\hline & 2 & 1 & 0 & 0 & 0 & \\
\hline & 3 & 1 & 0 & 0 & 0 & \\
\hline \multirow[t]{2}{*}{8} & 1 & 1 & 0 & 0 & 1 & 37.5 \\
\hline & 2 & 1 & 0 & 0 & 0 & \\
\hline \multirow[t]{3}{*}{9} & 1 & 1 & 0 & 0 & 1 & 50 \\
\hline & 2 & 1 & 0 & 0 & 1 & \\
\hline & 3 & 1 & 0 & 0 & 1 & \\
\hline \multirow[t]{3}{*}{10} & 1 & 1 & 0 & 0 & 0 & 41.7 \\
\hline & 2 & 1 & 0 & 0 & 0 & \\
\hline & 3 & 1 & 1 & 0 & 1 & \\
\hline \multirow[t]{3}{*}{11} & 1 & 1 & 0 & 0 & 1 & 50 \\
\hline & 2 & 1 & 0 & 0 & 1 & \\
\hline & 3 & 1 & 0 & 0 & 1 & \\
\hline \multirow[t]{2}{*}{12} & 1 & 1 & 0 & 0 & 0 & 25 \\
\hline & 2 & 1 & 0 & 0 & 0 & \\
\hline \multirow[t]{3}{*}{13} & 1 & 1 & 0 & 0 & 0 & 33.3 \\
\hline & 2 & 1 & 0 & 0 & 0 & \\
\hline & 3 & 1 & 0 & 0 & 1 & \\
\hline \multirow[t]{3}{*}{14} & 1 & 1 & 0 & 0 & 0 & 25 \\
\hline & 2 & 1 & 0 & 0 & 0 & \\
\hline & 3 & 1 & 0 & 0 & 0 & \\
\hline \multirow[t]{3}{*}{15} & 1 & 1 & 0 & 0 & 0 & 25 \\
\hline & 2 & 1 & 0 & 0 & 0 & \\
\hline & 3 & 1 & 0 & 0 & 0 & \\
\hline \multicolumn{2}{|c|}{ Persentase } & 100 & 14.6 & 0 & 41.5 & 39.4 \\
\hline
\end{tabular}


Berdasarkan data pada Tabel 1, persentase rata-rata pada RPP yaitu sekitar 39,4\% menunjukkan bahwa guru tidak merencanakan pembelajaran yang mengembangkan keterampilan berpikir kreatif secara maksimal. Hal ini disebabkan jika pembelajaran mengacu kepada proses kreatif maka pembelajaran harus dimulai dari menemukan masalah, memecahkan masalah sampai mengkomunikasikannya (Munandar, 2009). Tingginya persentase pengembangan kelancaran bukan berarti guru sengaja merencanakan untuk mengembangkan kelancaran melainkan hanya untuk mengetahui pemahaman siswa. Melalui tanya jawab, guru merencanakan untuk mengajukan pertanyaan yang sudah dipersiapkan kepada siswa. Tanya jawab sebagai metode dipilih guru sebanyak 52,2\% dalam RPP, sedangkan tanya jawab dalam kegiatan pembelajaran direncanakan oleh setiap guru pada setiap RPP.

Persentase elaborasi diketahui dari perencanaan guru untuk menugaskan siswa mengerjakan Lembar Kerja Siswa (LKS) dan diskusi sehingga di akhir kegiatan pembelajaran ada kegiatan presentasi kelompok. Presentasi kelompok adalah sarana utama yang direncanakan sebagian besar guru untuk mengembangkan elaborasi, karena hampir seluruh guru merencanakan mengerjakan LKS maka persentase elaborasi juga akan besar walau tidak sebesar kelancaran.

Kesenjangan terlihat dari aspek originalitas karena belum tampak dikembangkan. Dalam RPP tidak satupun rumusan kegiatan menunjukkan pengembangan originalitas. Sementara pengembangan originalitas sangat berhubungan dengan aspek kelancaran dan keluwesan. Jika kelancaran dan keluwesan dikembangkan maksimal baik dalam kegiatan tanya jawab atau diskusi, maka ada kemungkinan guru akan mengembangkan originalitas, sebab originalitas akan muncul jika guru dapat mengembangkan kelancaran dan keluwesan (Evans, 1991). Semakin banyak dan beragam jawaban siswa akan semakin besar kemungkinan munculnya originalitas. Namun karena guru tidak dengan sengaja mengembangkan keterampilan berpikir dalam pembelajarannya maka kemunculan pengembangan kelancaran dan keluwesan berlangsung tidak maksimal.

Pengembangan rencana pembelajaran adalah tugas guru yang menentukan kualitas pembelajaran yang akan dilaksanakan. Dalam RPP, rumusan pembelajaran mengembangkan keterampilan berpikir kreatif dilakukan pada saat guru merumuskan pengalaman belajar, dan rumusan pengalaman belajar ada pada rumusan kegiatan pembelajaran. Setiap guru sudah membuat rencana pembelajaran sesuai dengan petunjuk dalam Standar Proses. Hal ini juga ditemukan Gunawan (2009) dalam penelitiannya bahwa guru-guru membuat rencana pembelajaran sesuai dengan petunjuk dari Depdiknas. Berdasarkan petunjuk dari Depdiknas maka guru merumuskan langkah-langkah pembelajaran mulai dari kegiatan awal, kegiatan inti dan kegiatan akhir. Namun rumusan langkah-langkah pembelajaran yang dikembangkan oleh guru tampak seperti "seragam". Kegiatan awal dalam RPP guru sebagian besar menggunakan tanya jawab untuk apersepsi, kegiatan inti diisi dengan ceramah untuk menjelaskan dan mengerjakan LKS. Selanjutnya pada kegiatan akhir siswa mengerjakan tes tulis yang sifatnya mengingat apa yang sudah dipelajari sebelumnya. Dalam RPP yang telah dikembangkan oleh guru tidak banyak terdapat rumusan pembelajaran yang dapat membantu mengembangkan keterampilan berpikir kreatif.

Menurut Rustaman (2005) ada tiga faktor yang harus diperhatikan dalam merumuskan pengalaman belajar yaitu materi yang akan dibahas, kesiapan siswa, dan fasilitas. Dengan demikian bagian RPP yang bertujuan untuk mengembangkan aspek berpikir kreatif dapat tergambar pada rumusan pengalaman belajar. Untuk itu terlebih dahulu guru harus menguasai materi dengan baik. Tapilouw (1997) dalam hasil penelitiannya mengatakan bahwa pemahaman konsep sangat penting dalam kreativitas IPA. Selanjutnya dikatakan bahwa dengan menguasai materi, guru akan mudah merencanakan suatu metode yang tepat untuk materi tertentu, apakah materi tersebut cocok 
menggunakan metode ceramah, demonstrasi, pengamatan atau metode lain. Ketepatan merencanakan metode akan menentukan keberhasilan pembelajaran. Hasil penelitian Rochintaniawati (2010) menjelaskan bahwa kemampuan guru dalam menguasai content knowledge, pedagogical knowledge dan pedagogical content knowledge akan menjadikan pembelajaran IPA di sekolah dasar lebih bermakna.

Untuk mengembangkan keterampilan berpikir kreatif guru harus mencari jalan agar sarana prasarana tidak menjadi masalah. Pembelajaran yang kreatif adalah pembelajaran yang mendorong siswanya untuk mengembangkan gagasan yang ada dengan menggunakan sumber belajar yang ada (Indrawati \& Setiawan, 2009). Meskipun ketersediaan fasilitas memang harus diperhatikan dalam merumuskan pengalaman belajar akan tetapi jika guru dapat mengembangkan keterampilan berpikir siswa maka siswa akan berusaha mencari sendiri alat dan bahan yang diperlukan asalkan mereka paham akan tugasnya. Oleh sebab itu siswa harus diberi kesempatan untuk mengembangkan inkuiri dan keterampilan proses sains dari awal saat merencanakan.

Beberapa guru merumuskan kegiatan pembelajaran menggunakan metode tanya jawab dan pengamatan sesuai langkah-langkah LKS. LKS yang ada berupa petunjuk kerja, dan pengalaman belajar yang dirumuskan tidak mengandung kegiatan yang mengembangkan keterampilan berpikir seperti pembelajaran IPA yaitu menggunakan inkuiri. Sementara inkuiri adalah salah satu cara untuk meningkatkan keterampilan berpikir kreatif dalam pelajaran IPA (Pulaila, et.al., 2007; Budiman, et.al., 2008). LKS hendaknya mengacu pada kegiatan siswa untuk menemukan agar keterampilan berpikir kreatif siswa dapat terlatih. LKS yang ada berisi tentang penjelasan alat dan bahan serta langkah pengerjaan yang tertulis lengkap sehingga siswa hanya melaksanakan saja. Keadaan ini menandakan guru tidak memberi keleluasaan dan kebebasan kepada siswa untuk berkreasi sendiri dalam memecahkan masalah sehingga keterampilan berpikir kreatif siswa tidak berkembang.

Guru hendaknya merencanakan kegiatan yang tidak hanya membuat siswa mengerjakan tetapi juga berpikir. Misalnya jika yang dipilih metode diskusi maka guru hendaknya menampilkan permasalahan yang harus dipecahkan siswa secara berkelompok atau dengan diskusi kelas (Rustaman, 2005). Jika yang dipilih metode tanya jawab maka pertanyaan-pertanyaan guru harus dipersiapkan sehingga seluruh materi yang akan dibahas dapat terjawab melalui tanya jawab. Jika metode eksperimen yang dipilih maka permasalahan yang dipilih harus dipecahkan siswa dengan memberi kebebasan kepada siswa untuk merencanakan eksperimen sendiri. Jika inkuiri yang dipilih guru adalah inkuiri terbimbing maka guru memberikan permasalahan yang harus dipecahkan siswa (Rustaman, 2005) namun tetap langkah-langkah ditentukan oleh siswa. Selanjutnya dalam presentasi hasil kegiatan, siswa diberi kesempatan untuk mereview hasil kegiatannya dan diberi kesempatan untuk mempertimbangkan cara-cara alternatif yang dapat digunakan untuk memecahkan masalah sehingga siswa mengenali keterampilan apa yang masih perlu ditingkatkan (Rustaman, 2005). Pada setiap langkah direncanakan ada tanya jawab sehingga aspek kelancaran siswa dapat dilatih. Pada intinya, pengalaman belajar yang direncanakan guru harus membuat siswa aktif sehingga keterampilan berpikirnya berkembang. Guru harus memahami bahwa pembelajaran adalah belajar berpikir (Sanjaya, 2009). Jika metode-metode tersebut dilaksanakan sebagaimana mestinya maka keterampilan berpikir kreatif siswa akan berkembang.

Analisis RPP pada penelitian ini dilakukan pada setiap kelompok guru. Hasil analisis RPP setiap kelompok guru disajikan pada Gambar 1. 


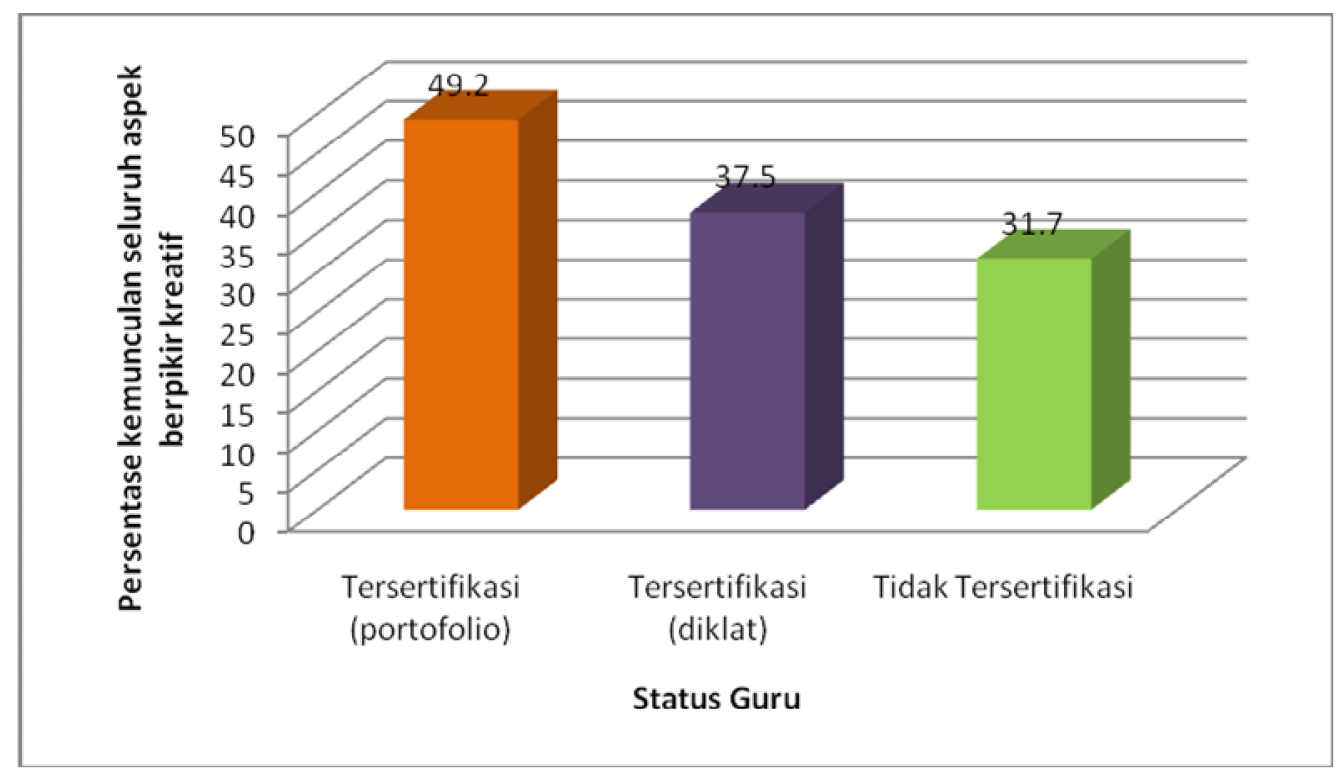

Gambar 1. Pengembangan keterampilan berpikir kreatif dalam RPP

Berdasarkan Gambar 1 terlihat pengembangan keterampilan berpikir kreatif yang dilakukan pada setiap kelompok guru masih kurang dari yang diharapkan. Pengembangan paling banyak oleh guru tersertifikasi melalui portofolio, namun pengembangan ini masih kurang dari 50\%. Jika dalam RPP guru kurang merencanakan keterampilan berpikir kreatif maka kemungkinan dalam PBM juga akan kurang. Berdasarkan hasil penelitian yang dilakukan oleh Rofi'uddin (2009) untuk mengembangkan keterampilan berpikir kreatif guru harus membuat perencanaan dengan baik .

Guru banyak mengembangkan kelancaran melalui tanya jawab. Bila pertanyaan kurang bersifat divergen, maka belum seluruh aspek berfikir kreatif dapat dikembangkan. Selanjutnya tidak semua guru merencanakan presentasi dalam RPP, oleh karena itu pengembangan elaborasi juga kurang. Jika dilaksanakan dengan baik, elaborasi bisa menjadi sarana untuk siswa mengkomunikasikan hasil kerjanya secara detail dan rinci (Meador, 2003; Filsaime, 2008).

\section{Pengembangan Keterampilan Berpikir Kreatif dalam Pelaksanaan Pembelajaran.}

Data hasil observasi pelaksanaan pembelajaran guru secara umum tertera pada Tabel 2. Dapat terlihat bahwa setiap guru mengembangkan setiap aspek keterampilan berpikir kreatif dalam jumlah yang bervariasi. Aspek originalitas sangat sedikit dikembangkan dalam pembelajaran. Aspek kelancaran sebagai aspek yang persentasenya paling banyak tidak dikembangkan secara maksimal. Seharusnya pada saat mengembangkan kelancaran, guru harus lebih mendorong siswa untuk mengeluarkan jawaban-jawaban lain sebagai alternatif untuk mengembangkan keluwesan. Jika keluwesan kurang dikembangkan maka originalitas tidak akan muncul. Cara yang dilakukan guru untuk mengembangkan kelancaran adalah dengan mengajukan pertanyaan. Dari dua jam pelajaran rata-rata waktu yang digunakan guru untuk mengembangkan kelancaran adalah 1,87 menit dan tidak ada guru yang mengembangkan kelancaran lebih dari 9 (sembilan) menit. Oleh karena waktu yang digunakan sangat sedikit maka untuk mencapai hasil pengembangan keterampilan berpikir kreatif yang maksimal tidak akan tercapai. 
Tabel 2. Durasi Munculnya Tiap Aspek Keterampilan Berpikir Kreatif dalam Pelaksanaan Pembelajaran (dalam menit)

\begin{tabular}{|c|c|c|c|c|c|c|}
\hline \multirow[t]{2}{*}{ Guru } & \multirow[t]{2}{*}{ Pembelajaran } & \multicolumn{4}{|c|}{ Aspek keterampilan berpikir kreatif } & \multirow[t]{2}{*}{ Jumlah } \\
\hline & & Kelancaran & Keluwesan & Originalitas & Elaborasi & \\
\hline \multirow{3}{*}{1} & 1 & 4,8 & 1,2 & 0,2 & 0 & 6,2 \\
\hline & 2 & 4,5 & 0,2 & 0 & 0,5 & 5,2 \\
\hline & 1 & 8,3 & 1,7 & 0,3 & 1 & 11,3 \\
\hline \multirow[t]{3}{*}{2} & 2 & 4,5 & 0,5 & 0,2 & 0,2 & 5,4 \\
\hline & 3 & 2,7 & 0,2 & 0 & 0,2 & 3,1 \\
\hline & 1 & 2,5 & 0,5 & 0 & 0,8 & 3,8 \\
\hline \multirow[t]{3}{*}{3} & 2 & 0,5 & 0 & 0 & 0 & 0,5 \\
\hline & 3 & 1,8 & 0,5 & 0 & 1 & 3,3 \\
\hline & 1 & 1,3 & 0,2 & 0 & 0 & 1,5 \\
\hline \multirow[t]{2}{*}{4} & 2 & 3 & 1 & 0 & 0,2 & 4,2 \\
\hline & 3 & 1 & 0,2 & 0 & 0,2 & 1,4 \\
\hline \multirow{3}{*}{5} & 1 & 3,2 & 0,8 & 0 & 0,2 & 4,2 \\
\hline & 2 & 2,7 & 1,3 & 0 & 0,3 & 4,3 \\
\hline & 1 & 5 & 1 & 0 & 0,2 & 6,2 \\
\hline \multirow[t]{3}{*}{6} & 2 & 1,8 & 0 & 0 & 0,3 & 2,1 \\
\hline & 3 & 1,7 & 0,2 & 0 & 1,3 & 3,2 \\
\hline & 1 & 2 & 0,3 & 0 & 0,2 & 2,5 \\
\hline \multirow[t]{2}{*}{7} & 2 & 1,3 & 0,2 & 0 & 0 & 1,5 \\
\hline & 3 & 0,5 & 0 & 0 & 0 & 0,5 \\
\hline \multirow{3}{*}{8} & 1 & 1,3 & 0 & 0 & 0 & 1,3 \\
\hline & 2 & 0 & 0 & 0 & 0 & 0 \\
\hline & 1 & 1 & 0 & 0 & 0,5 & 1,5 \\
\hline \multirow[t]{3}{*}{9} & 2 & 2,3 & 0,3 & 0 & 0,7 & 3,3 \\
\hline & 3 & 0,5 & 0 & 0 & 0,8 & 1,3 \\
\hline & 1 & 0,3 & 0,2 & 0 & 0 & 0,5 \\
\hline \multirow[t]{3}{*}{10} & 2 & 0,3 & 0,5 & 0 & 0 & 0,8 \\
\hline & 3 & 1,2 & 0,2 & 0 & 0 & 1,4 \\
\hline & 1 & 1,8 & 0,5 & 0 & 0 & 2,3 \\
\hline \multirow[t]{2}{*}{11} & 2 & 2 & 0 & 0 & 0 & 2 \\
\hline & 3 & 0,5 & 0 & 0 & 1 & 1,5 \\
\hline \multirow{2}{*}{12} & 1 & 1 & 0,3 & 0 & 0 & 1,3 \\
\hline & 2 & 0,8 & 0 & 0 & 0,3 & 1,1 \\
\hline
\end{tabular}


Tabel 2. (lanjutan)

\begin{tabular}{|c|c|c|c|c|c|c|}
\hline \multirow[t]{2}{*}{ Guru } & \multirow[t]{2}{*}{ Pembelajaran } & \multicolumn{4}{|c|}{ Aspek keterampilan berpikir kreatif } & \multirow[t]{2}{*}{ Jumlah } \\
\hline & & Kelancaran & Keluwesan & Originalitas & Elaborasi & \\
\hline \multirow{3}{*}{13} & 1 & 1 & 0 & 0 & 1,5 & 2,5 \\
\hline & 2 & 0,2 & 0 & 0 & 0 & 0,2 \\
\hline & 3 & 0,5 & 0 & 0 & 0 & 0,5 \\
\hline \multirow{3}{*}{14} & 1 & 3,2 & 0,2 & 0 & 0 & 3,4 \\
\hline & 2 & 1,8 & 0 & 0 & 0,3 & 2,1 \\
\hline & 3 & 2 & 0,2 & 0 & 0,2 & 2,4 \\
\hline \multirow{3}{*}{15} & 1 & 0,7 & 0 & 0 & 0,3 & 1 \\
\hline & 2 & 1 & 0 & 0 & 0 & 1 \\
\hline & 3 & 0,2 & 0 & 0 & 0 & 0,2 \\
\hline \multicolumn{2}{|c|}{ Rata-rata } & 1,87 & 0,30 & 0,02 & 0,30 & 2,49 \\
\hline
\end{tabular}

Berdasarkan Tabel 2 juga dapat diketahui bahwa secara umum rata-rata waktu yang digunakan guru untuk mengembangkan keterampilan berpikir kreatif adalah 2,49 menit dari dua jam pelajaran. Waktu tersebut terlalu singkat jika guru bermaksud ingin mengembangkan keterampilan berpikir. Untuk meningkatkan kemampuan siswa dalam berpikir kreatif maka proses pembelajaran harus mengacu kepada proses kreatif. Proses kreatif dan ilmiah dimulai dengan menemukan masalah sampai dengan menyampaikan hasil (Munandar, 2009). Torrance (dalam Munandar, 2009) menjelaskan bahwa proses kreatif dimulai dari merasakan kesulitan, masalah, kesenjangan, bagianbagian yang hilang atau sesuatu yang ditanyakan, kemudian membuat prediksi dan hipotesis tentang kekurangan tersebut, lalu mengevaluasi dan menguji prediksi dan hipotesis, selanjutnya merevisi dan menguji kembali hasilnya, dan terakhir mengkomunikasikan.

Dari setiap video pembelajaran guru yang diteliti, dapat dilihat bahwa secara umum metode ceramah sangat dominan dilakukan beberapa guru. Cara belajar seperti ini tidak akan mengembangkan keterampilan berpikir siswa karena menurut Mariati (2006) pendekatan pembelajaran yang dilakukan harus dua arah dimana siswa belajar aktif dalam berpikir, merencanakan, dan bertindak (active learning approach). Pendapat ini senada dengan pendapat Rustaman (2005) bahwa kelemahan metode ceramah adalah tidak merangsang kreativitas siswa sebab kadar Cara Belajar Siswa Aktif dalam metode ceramah sangat rendah. Siswa tidak akan terbiasa mengeluarkan pendapat, mencari informasi dan mengolah informasi. Sebenarnya terdapat potensi pada metode ceramah untuk meningkatkan keterampilan berpikir kreatif. Bila selama ceramah berlangsung, guru sekali-kali mengajukan pertanyaan kepada siswa, hal ini dapat mendorong siswa untuk mengembangkan kelancaran berpikirnya.

Kegiatan pembelajaran lain yaitu melalui metode demonstrasi, pengamatan dan percobaan serta diskusi pada umumnya tidak dimanfaatkan oleh guru sebagai sarana untuk mengembangkan keterampilan berpikir kreatif siswa. Guru tidak memberi kesempatan kepada siswa untuk mencari contoh-contoh lain dengan prinsip serupa dengan demonstrasi yang dilakukan oleh guru. Sementara berdasarkan hasil penelitian yang dilakukan oleh Suastra (2008), demonstrasi dan diskusi adalah metode pembelajaran yang mampu mengembangkan keterampilan berpikir kreatif. 
Metode percobaan dan pengamatan dilakukan secara berkelompok. Untuk melaksanakan percobaan atau pengamatan, kepada siswa dibagikan LKS untuk dikerjakan. Kegiatan ini tidak memfasilitasi siswa untuk mengembangkan keterampilan berpikirnya karena siswa hanya melakukan kegiatan (hands on) tanpa ada kegiatan berpikir (minds on). Masalah lain dari mengerjakan LKS yang dibuat guru dalam penelitian ini adalah banyak siswa yang tidak paham dengan apa yang dikerjakannya sehingga banyak siswa yang tidak perhatian pada tugasnya. Jika siswa tidak memahami materi yang diajarkan maka sulit bagi siswa untuk lebih berimajinasi mengeluarkan ide atau gagasan lain.

Dalam kegiatan diskusi siswa diberi pertanyaan seputar hasil kegiatan dan di akhir pembelajaran dipresentasikan di depan kelas dengan cara dibacakan. Pada umumnya kegiatan presentasi merupakan kegiatan untuk menyamakan jawaban. Presentasi yang hanya membaca tidak akan mengembangkan elaborasi. Seharusnya guru lebih mendorong siswa untuk menjelaskan temuannya sekaligus menjelaskan kelebihan dan kekurangannya. Sebenarnya diskusi dapat menjadi sarana untuk mengembangkan kelancaran dan keluwesan. Diskusi yang benar harus diawali dengan sebuah permasalahan yang harus dipecahkan siswa dalam kelompoknya sehingga ada proses berbagi gagasan, menyimak penjelasan teman dan mempertahankan pendapat (Rustaman, 2005). Menurut Meador (2003) jika siswa berkesempatan untuk menjelaskan hasil kegiatannya melalui presentasi maka guru harus mendorong siswa untuk lebih rinci menjelaskan hasil temuannya. Dengan demikian, dalam presentasi siswa tidak sekedar membacakan hasil kerjanya namun sekaligus menjelaskan agar keterampilan elaborasi siswa akan berkembang.

Pembahasan sebelumnya telah dikatakan bahwa pembelajaran IPA dengan pendekatan inkuiri dapat mengembangkan keterampilan berpikir kreatif. Bahkan pengembangan keterampilan berpikir kreatif melalui inkuiri dapat dilakukan pada evaluasi. Evaluasi yang diberikan dapat berupa tes dan non tes (Suastra, 2008). Soal tes hendaknya berupa pertanyaan divergen (terbuka) agar bisa melatih siswa untuk mengemukan berbagai alternatif jawaban.

Berdasarkan hasil observasi pembelajaran, jarang sekali terdapat soal evaluasi yang dapat mengukur kemampuan siswa dalam berpikir kreatif. Sebagian besar soal berisi pertanyaan untuk mengingat yang tingkat kognitifnya paling rendah. Meskipun dalam pembelajaran guru melaksanakan kegiatan inkuiri, seperti pengamatan dan percobaan, namun soal evaluasi yang diberikan tidak mengukur kemampuan siswa untuk berpikir seputar kegiatan inkuiri yang dilakukan.

Gambaran umum waktu yang digunakan oleh guru tersertifikasi (portofolio), guru tersertifikasi (diklat), dan guru tidak tersertifikasi disajikan dalam Gambar 2.

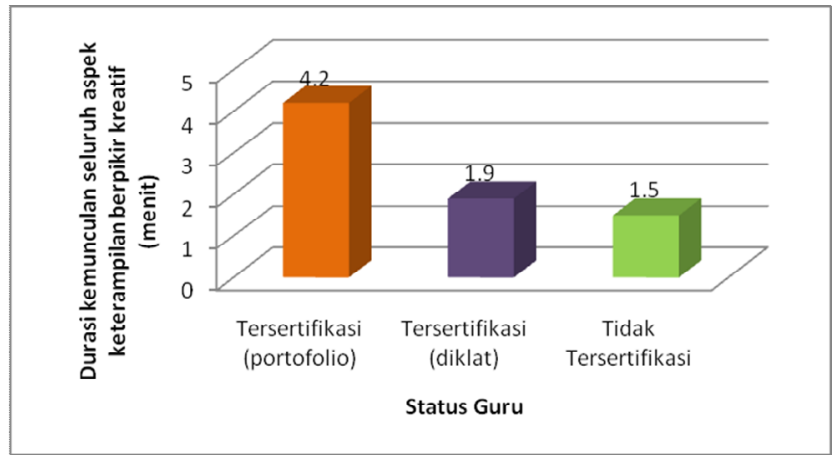

Gambar 2. Durasi waktu pengembangan keterampilan berpikir kreatif dalam pembelajaran 
Berdasarkan Gambar 2 terlihat bahwa seluruh kelompok guru sudah berupaya mengembangkan keterampilan berpikir kreatif meskipun belum maksimal. Guru tersertifikasi melalui portofolio paling banyak mengembangkan keterampilan berpikir kreatif dalam pelaksanaan pembelajaran yaitu 4,2 menit dari dua jam pelajaran. Namun kegiatan yang dilakukan dalam waktu 4,2 menit untuk mengembangkan keterampilan berpikir kreatif tentu sangat kurang. Kegiatan yang mengacu kepada proses kreatif pasti membutuhkan waktu banyak karena pembelajaran harus dimulai dengan menemukan masalah sampai mengkomunikasikan pemecahan masalah.

Tanya jawab paling banyak dilakukan untuk mengembangkan kelancaran terutama pada kegiatan awal. Namun temuan menunjukkan pertanyaan yang diajukan hanya seputar ingatan dan bahkan pertanyaan yang jawabannya sudah ada di buku. Hasil penelitian Mariati (2006) menjelaskan bahwa untuk mengembangkan berpikir kreatif maka pertanyaan yang diajukan guru harus berupa pertanyaan divergen. Pendapat senada dikemukakan oleh Sumarmo (2010) bahwa pertanyaan terbuka (divergen) akan memberi kesempatan kepada siswa untuk memberikan jawaban benar lebih dari satu dan berbeda sehingga mendorong siswa berpikir fleksibel atau lentur.

\section{Pengembangan Keterampilan Berpikir Kreatif yang Dilakukan oleh Guru Tersertifikasi dan Tidak Tersertifikasi Dalam RPP.}

Data hasil analisis RPP dan PBM guru tersertifikasi dan tidak tersertifikasi disajikan pada Gambar 3. Berdasarkan Gambar 3 diperoleh rata-rata pengembangan keterampilan berpikir kreatif oleh kelompok guru tersertifikasi (portofolio) adalah 28,1\%, oleh kelompok guru tersertifikasi (diklat) adalah $20,3 \%$ dan oleh kelompok guru tidak tersertifikasi adalah $17,2 \%$. Hasil penelitian ini sesuai dengan asumsi, bahwa guru tersertifikasi melalui portofolio adalah guru yang dianggap memiliki kemampuan paling tinggi untuk mengembangkan keterampilan berpikir kreatif sebab guru-guru ini adalah guru dengan pengalaman mengajar yang tinggi dan berpotensi di bidangnya. Sejak perencanaan dan kemudian dalam pelaksanaan pembelajaran, kelompok guru tidak tersertifikasi paling rendah mengembangkan keterampilan berpikir kreatif. Hal ini terjadi karena jika guru berceramah maka ceramah terlalu dominan dan jika guru memberi tugas mengerjakan LKS maka kegiatan ini terlalu dominan, sementara kegiatan dalam LKS tidak mendorong siswa untuk berpikir.

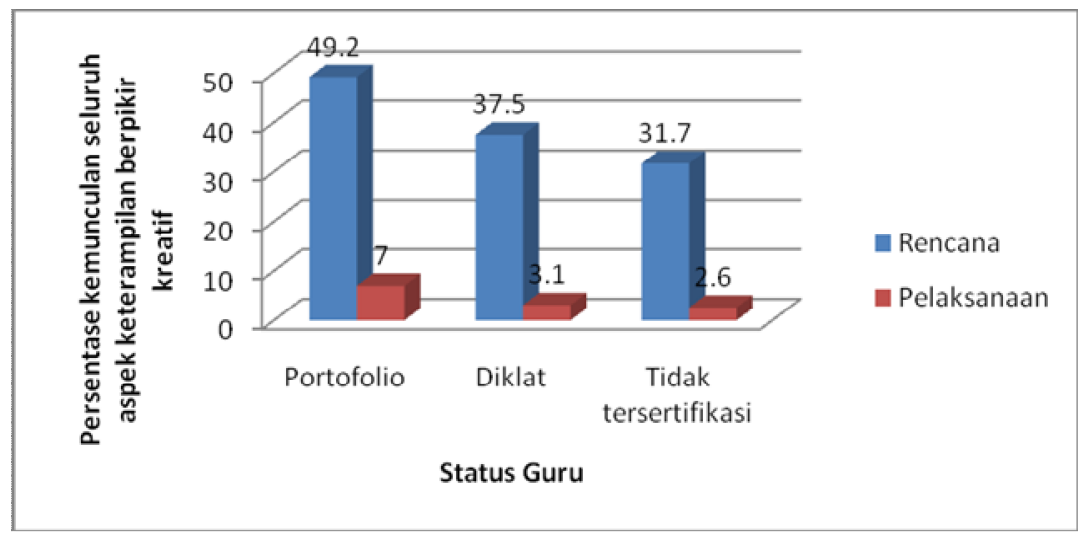

Gambar 3. Perbandingan pengembangan keterampilan berpikir kreatif dalam rencana dan pelaksanaan pembelajaran 
Pelaksanaan RPP yang tidak maksimal terlihat dari terjadinya penurunan drastis pada pengembangan keterampilan berpikir kreatif dari perencanaan ke pelaksanaan pembelajaran. Sebenarnya guru tampak berusaha untuk menggunakan metode dan kegiatan yang dirumuskan dalam RPP. Namun pemahaman guru terhadap pelaksanaan suatu metode yang tepat masih kurang. Dengan melihat kondisi seperti ini, pedagogical kowledge dan Pedagogical Content Knowledge (PCK) guru masih perlu mendapatkan binaan lebih lanjut. Rochintaniawati (2010) dalam hasil penelitiannya terhadap guru IPA di sekolah dasar di Cimahi dan Bandung Barat berpendapat bahwa keterampilan guru yang masih harus ditingkatkan adalah pengetahuan pedagogical knowledge dan Pedagogical Content Knowledge (PCK).

\section{Peranan Pembelajaran IImu Pengetahuan Alam (IPA) dalam Meningkatkan Kemampuan Siswa Berpikir Kreatif.}

Berikut disajikan skor RPP, PBM, dan skor tes siswa (Tabel 3) guna melihat peranan pembelajaran IPA (RPP dan PBM) terhadap kemampuan siswa berpikir kreatif siswa.

Tabel 3 menunjukkan bahwa tidak ada pola yang jelas antara hasil pembelajaran yang mengembangkan keterampilan berpikir kreatif dengan keterampilan siswa berpikir kreatif. Sebagai contoh, terlihat bahwa rata-rata skor siswa tertinggi diperoleh dari siswa guru 2. Guru 2 sendiri memiliki persentase PBM terbesar. Berarti proses pembelajaran yang dialami siswa guru 2 berdampak pada keberhasilan siswa meraih skor tertinggi dalam tes. Hal yang berbeda terjadi pada guru 1 yang memiliki persentase tinggi dalam PBM karena rata-rata skor siswanya paling rendah. Hal ini berarti pembelajaran yang dilakukan guru 1 tidak mampu meningkatkan kemampuan siswa berpikir kreatif.

Tabel 3. Kemunculan Keterampilan Berpikir Kreatif dalam RPP, Proses Pembelajaran dan

\begin{tabular}{cccc}
\multicolumn{4}{c}{ Hasil Skor Tes Siswa } \\
\hline Guru & Persentase RPP & Persentase PBM & Rata-rata skor siswa \\
\hline 1 & 37,5 & 9,5 & 4,09 \\
2 & 33,3 & 11 & 13,31 \\
3 & 50 & 4,2 & 7,84 \\
4 & 50 & 3,9 & 10,66 \\
5 & 75 & 7,1 & 7,96 \\
6 & 33,3 & 6,4 & 8,03 \\
7 & 25 & 2,5 & 4,17 \\
8 & 37,5 & 1,1 & 9,84 \\
9 & 50 & 3,4 & 9,86 \\
10 & 41,7 & 1,5 & 5,24 \\
11 & 50 & 3,2 & 7,92 \\
12 & 25 & 2,0 & 4,09 \\
13 & 33,3 & 1,7 & 7,13 \\
14 & 25 & 4,4 & 4,21 \\
15 & 25 & 1,2 & 5,43 \\
\hline Rata-rata & 39,4 & 4,2 & 7,3
\end{tabular}


Selain itu keterampilan berpikir kreatif siswa juga didukung oleh faktor internal siswa karena siswa yang mendapat skor tes berpikir kreatif yang tinggi adalah siswa yang juga memiliki prestasi dalam pelajaran IPA yang baik di kelasnya. Renzulli (1979 dalam Supriadi, 1994) menjelaskan bahwa prestasi kreatif didukung oleh tiga prasyarat yaitu kemampuan intelektual yang memadai, motivasi dan komitmen untuk mencapai keunggulan. Ketiga prasyarat ini merupakan dorongan internal siswa.

\section{KESIMPULAN}

Dalam rencana pembelajaran, guru sudah mengembangkan keterampilan berpikir kreatif yaitu rata-rata 39,4\%. Aspek berpikir kreatif yang paling banyak dikembangkan guru adalah kelancaran melalui metode tanya jawab. Aspek originalitas paling sedikit dikembangkan karena guru kurang maksimal mengembangkan kelancaran dan keluwesan sehingga ide siswa yang original tidak muncul. Guru tersertifikasi melalui portofolio paling banyak mengembangkan keterampilan berpikir kreatif dalam RPP.

Dalam pelaksanakan pembelajaran, waktu yang digunakan guru untuk mengembangkan keterampilan berpikir kreatif sangat sedikit yaitu 2,49 menit. Dengan demikian dapat dikatakan bahwa guru sangat kurang mengembangkan keterampilan berpikir kreatif dalam pelaksanaan pembelajaran. Aspek keterampilan berpikir kreatif yang paling banyak dikembangkan guru adalah aspek kelancaran dan yang paling sedikit adalah originalitas. Guru tersertifikasi melalui portofolio paling banyak mengembangkan keterampilan berpikir kreatif dalam pembelajaran.

Dalam rencana dan pelaksanaan, guru tersertifikasi lebih banyak mengembangkan keterampilan berpikir kreatif. Dengan demikian guru tersertifikasi memiliki kemampuan yang lebih dibandingkan guru tidak tersertifikasi. Namun secara umum guru belum maksimal dalam melaksanakan RPP dalam pembelajarannya.

Pembelajaran IPA di sekolah dasar tidak memiliki peranan yang berarti dalam meningkatkan kemampuan siswa berpikir kreatif, karena tidak ada pola hubungan yang jelas antara pembelajaran IPA dengan kemampuan siswa berpikir kreatif. Diduga kemampuan siswa dalam berpikir kreatif lebih dikarenakan oleh faktor internal siswa yaitu intelegensi dan motivasi.

\section{REFERENSI}

BSNP. (2006). Standar Isi. Jakarta: Depdiknas.

Budiman, et. al. (2008). Model pembelajaran latihan inkuiri untuk meningkatkan penguasaaan konsep energi rumah tangga dan keterampilan berpikir kreatif siswa SMP. Jurnal Penelitian Pendidikan IPA. Prodi IPA SPS UPI Bandung.

Cheng, V.M.Y. (2010). Teaching creative thinking in regular science lesson: Potential and obstacles of three different approaches in an asian context. Asia Pasipic Forum on Science Learning and Teaching [Online], Vol.1(17), 1 Tersedia: http://www.ied.edu.hk/apfslt/ download/v11_issue1_files/chengmy.pdf.

Evans, J.R. (1991). Creative thinking. Cincinnati. Ohio: South-Western Publishing Co.

Filsaime, D. K. (2008). Menguak rahasia berpikir kritis dan kreatif. Jakarta: Prestasi Pustaka.

Firman, H. \& Widodo, A. (2008). Panduan pembelajaran ilmu pengetahuan alam SD/MI. Jakarta: Pusat Perbukuan Depdiknas.

Gede Raka. (2009). Peningkatan mutu guru: Hati-hati jangan memanjat pohon yang salah. Makalah pada Seminar Nasional "Paradigma Baru Mutu Pendidikan di Indonesia" di UNY tanggal 25 April 2009. 
Gunawan, S. (2009) Analisis kesesuaian rencana pembelajaran yang dibuat guru SD dengan pelaksanaan pembelajaran sains. Tesis yang tidak dipublikasikan UPI Bandung.

Indrawati \& Setiawan. (2009). Pembelajaran aktif, kreatif dan menyenangkan untuk guru SD. Jakarta: PPPPTK IPA.

Jalal, F.,et.al. (2009). Teacher certification in Indonesia. Departemen Pendidikan Nasional.

Jarvis, T. (1991). Children and primary science. New York: Nichols Publishing.

Juremi, S. \& Ayob, A. (2003). Menentukan kesahan alat ukur - alat ukur kemahiran berfikir kritis, kemahiran berfikir kreatif, Kemahiran proses sains dan pencapaian biologi. Diambil 17 Pebruari 2008, dari http://www.geocities.com/drwanrani/SabariaJuremi.doc

Mariati. (2006). Pengembangan kreativitas siswa melalui pertanyaan divergen pada mata pelajaran ilmu pengetahuan alam. Jurnal Pendidikan dan Kebudayaan, 063. Diambil dari http://jurnal.pdii.lipi.go.id/admin/jurnal/126306759773.pdf.

Meador, K. S. (2003). Thinking creatively about science: Suggestions for primary teachers. Diambil 17 Pebruari 2008, dari http://www.prufrock.com/client/client_pages/GCT_articles/ Science/Teaching_Science_to_Gifted_Children.cfm.

Munandar, U. (2009). Pengembangan kreatifitas anak berbakat. Jakarta: Rineka Cipta.

Permendiknas RI No. 41 Tahun 2007 tentang Standar Proses. Jakarta: Depdiknas.

Pullaila, A. et. al (2007). Model pembelajaran inkuiri terbimbing untuk meningkatkan penguasaan konsep dan keterampilan berpikir kreatif siswa SMA pada materi suhu dan kalor. Jurnal Penelitian Pendidikan IPA. Prodi IPA SPS UPI Bandung.

Rochintaniawati, D. (2010). Analisis kebutuhan guru dalam mengembangkan kurikulum dan pembelajaran IPA di sekolah dasar. Disertasi yang tidak dipublikasikan UPI Bandung. Tidak diterbitkan.

Rofi'uddin. (2009). Model pendidikan berpikir kritis-kreatif untuk siswa sekolah dasar. Diambil 17 Pebruari 2008, dari http://www.infodiknas.com/model-pendidikan-berpikir-kritis-kreatif-untuksiswa-sekolah-dasar-2l.

Rustaman, N. (2005). Strategi belajar mengajar biologi. Malang: UM Press.

Sanjaya, W. (2009). Kurikulum dan pembelajaran. Jakarta: Kencana Prenada Media Group.

Siegler, R.S. \& Alibali, M. W. (2005). Children's thinking. New Jersey: Pearson Prentice Hall.

Suastra, I. W. (2008). Teaching science model for developing students' creative thinking ability. Proceedings The $2^{\text {nd }}$ International Seminar on Science Education. Bandung, 18 Oktober 2008.

Tapilouw, F. S. (1997). Kreativitas berpikir pada anak usia sekolah dasar dalam memecahkan masalah-masalah IPA. Disertasi yang tidak dipublikasikan Jurusan Pendidikan IPA. Program Pasca Sarjana IKIP Bandung.

Widodo, A. (2006). The feature of biology lesson: Result of a video study? Paper Presented at The $2^{\text {nd }}$ UPI-UPSI Joint International Conference August 8-9, 2006 in Bandung. Bandung: Jurusan Pendidikan Biologi. Tidak diterbitkan. 
Lampiran 1

\section{Kisi-kisi lembar analisis RPP \\ Kelancaran:}

Guru merencanakan kegiatan yang mendorong siswa untuk mengeluarkan banyak ide, gagasan atau solusi. Misalnya:

a. Guru merencanakan melibatkan siswa dalam menentukan kegiatan pembelajaran.

b. Guru merencanakan kegiatan pembelajaran yang permasalahannya dimulai dari pertanyaan siswa.

\section{Keluwesan}

Guru merencanakan kegiatan untuk memotivasi siswa agar mengeluarkan macam-macam ide, gagasan, solusi atau jawaban dari berbagai sudut pandang atau situasi. Misalnya:

a. Guru merencanakan metode pembelajaran yang sifatnya diskusi dan memecahkan masalah, misalnya dalam kondisi tertentu siswa diminta membuat suatu percobaan dengan menerapkan konsep-konsep yang sudah dimilikinya tentang gaya.

b. Guru menggunakan alat, bahan, atau media yang bervariasi.

c. Guru meminta siswa menjelaskan alat dan bahan dan alternatif solusi jika alat dan bahan yang direncanakan tidak ada.

\section{Originalitas}

Guru merencanakan kegiatan yang mendorong siswa untuk mengeluarkan ide, gagasan, solusi atau jawaban yang unik dan asli. Misalnya:

a. Guru melakukan suatu kegiatan yang mendorong siswa agar mampu mengeluarkan ide-ide yang lain dari biasanya.

b. Guru menggunakan berbagai sumber belajar untuk menginspirasi siswa agar mengeluarkan ide atau gagasannya.

\section{Elaborasi}

Guru merencanakan untuk memberi kesempatan kepada siswa agar menjelaskan alasan atas ide, gagasan, solusi dan jawaban dengan rinci. Misalnya:

a. Guru merencanakan diskusi sehingga siswa memperoleh kesempatan untuk menjelaskan dasardasar ide-ide atau hasil kerjanya.

b. Guru merencanakan memberi kesempatan kepada setiap kelompok siswa untuk menjelaskan ide, gagasan atau hasil kerjanya.

\section{Kisi-kisi lembar observasi pembelajaran \\ Kelancaran}

Guru melakukan kegiatan pembelajaran yang mendorong siswa untuk mengeluarkan ide, gagasan atau solusi, misalnya:

a. Guru membuat suatu pola atau kecenderungan peristiwa sehingga siswa mampu mengemukakan pertanyaan tentang peristiwa tersebut dan membuat prediksi.

b. Guru menghargai pendapat siswa dan membesarkan hati siswa agar tidak takut salah.

c. Guru memberi contoh kegiatan yang kreatif. 
d. Guru membimbing siswa untuk bereksperimen atau berdiskusi untuk memecahkan masalah..

e. Guru memberi peluang kepada siswa untuk menyatakan gagasan atau hipotesis.

f. Guru mengajukan pertanyaan divergen untuk membuka peluang kepada siswa dalam berpikir kreatif.

g. Guru menampung semua pendapat siswa, dengan menulis di papan tulis atau mengkomunikasikan kepada siswa lain.

\section{Keluwesan}

Guru melakukan kegiatan pembelajaran yang memotivasi dan mendorong siswa untuk mengeluarkan ide, gagasan atau solusi yang bermacam-macam dilihat dari berbagai sudut pandang, seperti :

a. Guru menghargai setiap pendapat siswa dengan memberi kesempatan kepada siswa untuk melaksanakan kegiatan sesuai idenya.

b. LKS dalam pembelajaran tidak diberikan guru, namun tugas-tugas dibuat bersama.

c. Siswa diberi kesempatan untuk menguji hipotesis atau gagasan dalam suatu kegiatan dengan menggunakan alat dan bahan yang bermacam-macam.

d. Guru tidak bersikap otoriter dan memaksakan kehendak.

e. Siswa diberi kesempatan untuk mengekplorasi alat dan bahan.

f. Siswa diberi kesempatan untuk mengaplikasikan ide atau gagasannya dalam situasi yang lain atau dengan menggunakan alat dan bahan yang lain.

\section{Originalitas}

Guru melakukan kegiatan pembelajaran yang mendorong siswa untuk mengeluarkan ide-ide aslinya yang berbeda dari yang lain, seperti :

a. Guru memberi kesempatan kepada siswa untuk merancang suatu kegiatan untuk memecahkan masalah .

b. Guru memotivasi siswa untuk menggunakan alat dan bahan yang lain dari biasanya tetapi tetap dapat digunakan untuk memecahkan masalah.

c. Guru tidak memaksa siswa untuk berpikir keras dalam mengeluarkan ide unik namun difokuskan untuk mencari keunikan dalam gagasan-gagasan yang telah dikemukakan siswa dalam kelancaran dan keluwesan.

\section{Elaborasi}

Guru memberi kesempatan kepada siswa untuk menjelaskan hasil kerjanya dengan rinci, seperti:

a. Guru memberi kesempatan kepada siswa untuk unjuk kebolehan.

b. Guru menekankan proses daripada hasil.

c. Guru memberi kesempatan kepada siswa untuk menjelaskan proses guna memecahkan masalah.

\section{Tes keterampilan berpikir kreatif siswa.}

Tes terdiri dari 8 (delapan) buah pertanyaan dengan skor maksimal 7 (tujuh) untuk setiap soal. Soal-soal dalam tes siswa tersebut mewakili keterampilan siswa dalam beberapa aktivitas pembelajaran yang bisa mengembangkan keterampilan berpikir kreatif seperti yang dikemukakan oleh Juremi dan Ayob (2003) yaitu bertanya, menerka sebab, menerka akibat, mengajukan alternatif pemecahan masalah atau memperbaiki hasil, menjelaskan kegunaan suatu objek dan menjelaskan kemungkinan yang akan terjadi. Semua soal disesuaikan dengan materi pelajaran yang telah 
dipelajari siswa sebelum tes dilakukan yaitu tentang Gaya dan Pesawat Sederhana serta tentang Cahaya dan Alat Optik. Kisi-kisi tes keterampilan berpikir kreatif siswa ada pada Tabel 1.

Tabel 1. Kisi-kisi Tes Keterampilan Berpikir Kreatif Siswa

\begin{tabular}{lc}
\hline Isi soal & Nomor soal \\
\hline Menjelaskan kemungkinan yang akan terjadi pada suatu peristiwa. & $1,3,7$ \\
Menjelaskan fungsi suatu objek. & 2 \\
Mengajukan pertanyaan sebanyak-banyaknya. & 4 \\
Menjelaskan sebab akibat & 5,8 \\
Memperbaiki hasil & 6 \\
\hline Jumlah soal tes = 8 buah & \\
\hline
\end{tabular}

